\title{
Design and application of a mobile ground-based observatory for continuous measurements of atmospheric trace gas and criteria pollutant species
}

\author{
S. E. Bush ${ }^{1}$, F. M. Hopkins ${ }^{2}$, J. T. Randerson ${ }^{2}$, C.-T. Lai ${ }^{3}$, and J. R. Ehleringer ${ }^{1,4}$ \\ ${ }^{1}$ Dept. of Biology, University of Utah, Salt Lake City, Utah, USA \\ ${ }^{2}$ Dept. of Earth System Science, University of California, Irvine, California, USA \\ ${ }^{3}$ Dept. of Biology, San Diego State University, San Diego, California, USA \\ ${ }^{4}$ Global Change and Sustainability Center, University of Utah, Salt Lake City, Utah, USA
}

Correspondence to: S. E. Bush (susanelainebush@gmail.com)

Received: 9 July 2014 - Published in Atmos. Meas. Tech. Discuss.: 6 January 2015

Revised: 9 May 2015 - Accepted: 22 May 2015 - Published: 26 August 2015

\begin{abstract}
Ground-based measurements of atmospheric trace gas species and criteria pollutants are essential for understanding emissions dynamics across space and time. Gas composition in the lower $50 \mathrm{~m}$ of the atmosphere has the greatest direct impacts on human health as well as ecosystem processes; hence data at this level are necessary for addressing carbon-cycle- and public-health-related questions. However, such surface data are generally associated with stationary measurement towers, where spatial representation is limited due to the high cost of establishing and maintaining an extensive network of measurement stations. We describe here a compact mobile laboratory equipped to provide highprecision, high-frequency, continuous, on-road synchronous measurements of $\mathrm{CO}_{2}, \mathrm{CO}, \mathrm{CH}_{4}, \mathrm{H}_{2} \mathrm{O}, \mathrm{NO}_{x}, \mathrm{O}_{3}$, aerosol, meteorological, and geospatial position data. The mobile laboratory has been deployed across the western USA. In addition to describing the vehicle and its capacity, we present data that illustrate the use of the laboratory as a powerful tool for investigating the spatial structure of urban trace gas emissions and criteria pollutants at spatial scales ranging from single streets to whole ecosystem and regional scales. We assess the magnitude of known point sources of $\mathrm{CH}_{4}$ and also identify fugitive urban $\mathrm{CH}_{4}$ emissions. We illustrate how such a mobile laboratory can be used to better understand emissions dynamics and quantify emissions ratios associated with trace gas emissions from wildfire incidents. Lastly, we discuss additional mobile laboratory applications in health and urban metabolism.
\end{abstract}

\section{Introduction}

Measurements of atmospheric trace gas species and criteria pollutants are essential for quantifying regional-to-global carbon cycle questions as well as ecosystem dynamics in both natural and urban ecosystems. There is an increasing need for high-frequency and high-resolution data at finer spatial and temporal scales across different ecosystems than have been available from either airborne or traditional fixedlocation ground-based systems (Crosson, 2008). The primary motivation for the measurement system described here was threefold: (a) to assess spatial patterns of fossil fuel emissions in an urban ecosystem (e.g., $\mathrm{CO}_{2}, \mathrm{CO}, \mathrm{CH}_{4}$, and $\mathrm{O}_{3}$ along urban to forest ecosystem gradients); (b) to quantify trace gas emissions ratios from wildfires in the western USA; and (c) to provide data for regional-scale modeling and data integration among existing stationary measurement towers.

Urban ecosystems play an important role in the global carbon cycle and climate change due to their significant impact on the composition of the atmosphere associated primarily with fossil fuel combustion. They are directly responsible for the largest net source of carbon dioxide to the atmosphere on an annual basis and represent a significant net source of anthropogenic methane, although the magnitude associated with contributing processes for methane from cities is far less understood (Canadell et al., 2007; IEA, 2008; Wunch et al., 2009; Dhakal, 2010; IPCC, 2013; Miller et al., 2013). Today roughly $50 \%$ of the world's population resides in cities; by 2050 more than $75 \%$ of the world's population is expected to 
be urban (UN, 2011). Significant methodological limitations and uncertainties remain with respect to the science community's ability to quantify fossil fuel emissions from urban areas, particularly at fine spatial and temporal scales (Gurney et al., 2009, 2012).

Previous studies focused on greenhouse gas emissions from cities have included inventory, direct measurements alone or in combination with atmospheric transport models or stable isotopic data, and model-based approaches. Carbon dioxide emissions inventories for cities have historically occurred at a coarse spatial scale, utilizing multiple methods including energy statistics and population census data, often scaled down from regional and national data sets, survey data, and modeling, and in many cases they are linked only to specific sectors of cities (Kennedy et al., 2009; Wunch et al., 2009; Dhakal, 2010). Higher-resolution inventories require using a combination of techniques to extrapolate emissions from buildings and road networks (Gurney et al., 2012). A number of studies have utilized measured data from stationary tower sites and satellite-based instruments to assess both variability in the magnitude of emissions over time and space and also in combination with stable isotopic data to partition total emissions into component source parts (Pataki et al., 2003; Riley et al., 2008; Wunch et al., 2009; NRC, 2010; Haiduc and Beldean-Galea, 2011; Turnbull et al., 2011; Kort et al., 2012; Briber et al., 2013; Kort et al., 2013; Lietzke and Vogt, 2013; Newman et al., 2013; Schneising et al., 2013), while others have used a combination of tower-based measurement data and atmospheric transport models to estimate emissions (Strong et al., 2011; Brondfield et al., 2012; McKain et al., 2012; Brioude et al., 2013; Lauvaux et al., 2013; Nehrkorn et al., 2013).

The development of emissions model products with their estimates of carbon dioxide emissions at the county scale for the conterminous USA (e.g., VULCAN) (Gurney et al., 2009) and the whole city scale with spatial resolution down to the individual building level (HESTIA) (Gurney et al., 2012) have not yet been tested with trace gas observations at the parcel-to-city scales. In all of these cases, it is clear that, whether for integration of data between stationary tower measurement sites or collection of data to validate and/or improve current emissions model products, high-resolution data linked to a mobile platform would help improve our current understanding.

In addition to urban ecosystem fossil fuel emissions, emissions from wildfires represent a significant source of atmospheric $\mathrm{CO}_{2}, \mathrm{CO}, \mathrm{CH}_{4}$, other trace gases, and aerosols (Yokelson et al., 2013), and they are an important component of the global carbon budget. The gross flux of carbon from wildfires is approximately $2-3 \mathrm{PgC}$ per year, and is highly variable on interannual timescales (van der Werf et al., 2010). Quantification of carbon emissions from wildfires involves "bottom-up" inventories, remote sensing, and model-based estimates at various temporal and spatial scales (Spessa et al., 2013). Emissions of other trace gases are estimated from the product of total emissions and emissions factors that define the relationship of their emissions relative to the total amount of biomass combusted. Emissions factors are known to vary by fuel load type and moisture content, and across biomes (van Leeuwen and van der Werf, 2011). However, in practice, static emissions factors are typically used, as there often are not sufficient data to incorporate these sources of variation in emissions calculations. Hence, estimates of total trace gas emissions from wildfires would be greatly improved by acquisition of specific emissions factor data both over time for a given geographic location and wildfire incident and across space and different biome types. Acquisition of this kind of data necessarily requires a mobile measurement platform given the stochastic nature of these events. In addition, the ability to link these measurements with remotely sensed data products is a critical component for advancing the ability to assess wildfire emissions impacts at regional and global scales (Sommers et al., 2014).

Several studies have described the use of mobile laboratories to provide greenhouse gas mole fraction data at high spatial and temporal resolutions. In general, the mobile facilities have focused on the acquisition of atmospheric aerosol and criteria pollutant data (Bukowiecki et al., 2002; Westerdahl et al., 2005; Pirjola et al., 2009; Weimer et al., 2009; Drewnick et al., 2012) or measurement of one or more greenhouse gas species (Shorter et al., 1996; Farrell et al., 2013; Leifer et al., 2013; Phillips et al., 2013; Jackson et al., 2014). In cases where the capacity for the measurement of multiple variables exists, the facilities are typically large, oversized vans or recreational vehicle platforms, designed to provide stationary or mobile functionality but not both (Kolb et al., 2004; Herndon et al., 2005; Moore, 2009) - but see Hussein et al. (2008), Pirjola et al. (2009), and Drewnick et al. (2012) for examples capable of both, albeit all larger oversized van platforms relative to the mobile laboratory described here.

Here we describe a compact mobile laboratory equipped to provide continuous, on-road, high spatial and temporal resolution $\mathrm{CO}_{2}, \mathrm{CO}, \mathrm{CH}_{4}, \mathrm{H}_{2} \mathrm{O}, \mathrm{NO}_{x}, \mathrm{O}_{3}$, aerosol, meteorological, and geospatial data. We then present data illustrating applications for which this platform can be used to address carbon-cycle- and public-health-related objectives.

\section{Description of mobile observatory}

The mobile observatory was constructed using a compact, four-cylinder, two-passenger Ford Transit Connect van, equipped with dual sliding side doors and symmetrical rear doors in the cargo area, and the following exterior dimensions: $2.1 \mathrm{~m}$ width, $4.5 \mathrm{~m}$ length, and $2.0 \mathrm{~m}$ height. This vehicle was selected to achieve both data acquisition and public outreach goals. The floor of the cargo area was modified with rubber matting, and a series of infrastructural components were designed and fabricated to facilitate high-quality atmospheric trace gas measurements. These components in- 


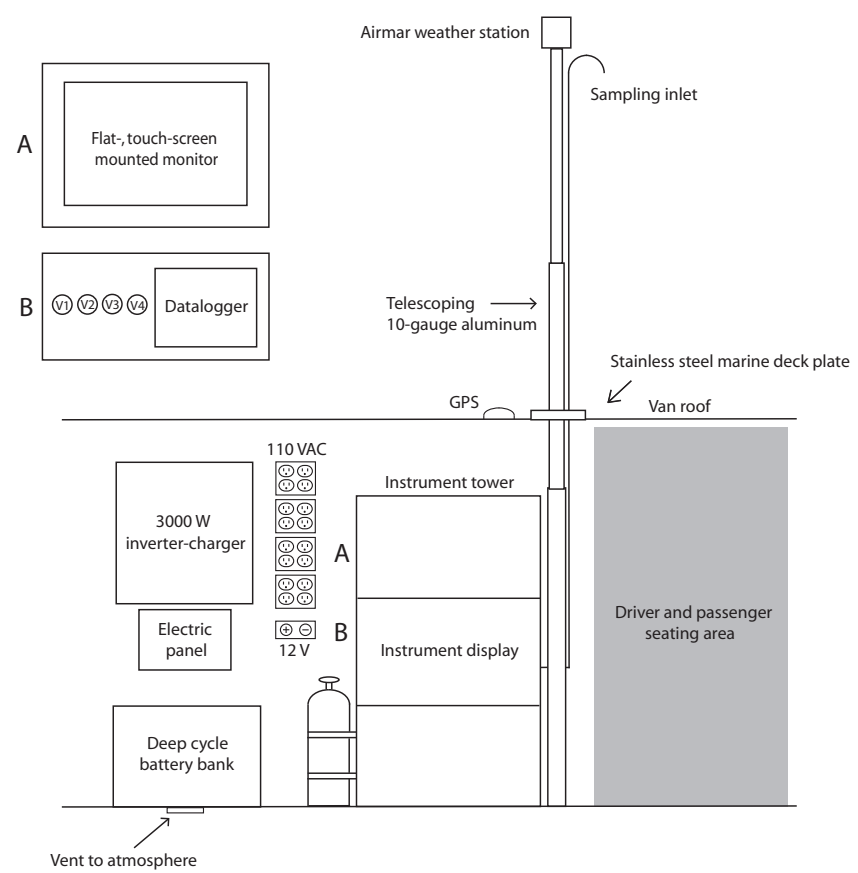

Figure 1. Schematic of mobile laboratory components and orientation. The viewing angle is from the passenger side of the vehicle. Letters A and B show panel components mounted to the instrument rack, which face the rear of the vehicle.

cluded a tower instrument rack, a telescoping sampling mast for attaching trace gas inlet plumbing, a high-pressure cylinder cage, and an atmospheric flask sampling line (Fig. 1). The steel instrument rack $(0.6 \mathrm{~m}$ width; $0.6 \mathrm{~m}$ length; $1.1 \mathrm{~m}$ height) was fastened to both the vehicle floor and each sidewall above each sliding door for additional stability. The telescoping sampling mast $(0.08 \mathrm{~m}$ OD base cylinder, with smaller cylinder segments extending to $0.03 \mathrm{~m}$ OD at the top) was constructed of 10-gauge, aerospace grade aluminum; was designed to fit inside the vehicle when fully collapsed; and extend as much as $5 \mathrm{~m}$ above the roof of the vehicle to provide multiple sampling height options for both mobile and stationary applications. To facilitate the movement of the sampling mast into and out of the vehicle, an access hole was cut out of the roof of the vehicle and a stainless-steel mounting plate with a removable threaded lid and gasket seal were installed. The resulting access opening measured $0.1 \mathrm{~m}$ in diameter. The sampling mast was fastened with mounting brackets to the side of the instrument rack on the interior of the vehicle directly below the roof access hole. A steel cage with the capacity to secure three high-pressure, $7 \mathrm{~L}$ cylinders was fabricated and fastened to the instrument rack on the side opposite the sampling mast attachment. An atmospheric flask sampling apparatus was constructed of aluminum and perforated steel plate components and attached to the rear, passenger side, interior wall of the vehicle to facilitate collection of both $100 \mathrm{~mL}$ and $2 \mathrm{~L}$ atmospheric air samples in glass flasks sealed with Teflon stopcocks.

\subsection{Trace gas instrumentation}

Two cavity ring-down spectrometers for measuring trace gas species were installed on the instrument tower. One measured $\mathrm{CO}_{2}, \mathrm{CO}$, and $\mathrm{H}_{2} \mathrm{O}$ (Picarro model G1302 Sunnyvale, CA) at approximately $2 \mathrm{~s}$ intervals and the other $\mathrm{CO}_{2}, \mathrm{CH}_{4}$, and $\mathrm{H}_{2} \mathrm{O}$ (Picarro G1301) at approximately $3 \mathrm{~s}$ intervals. Additional technical information for these systems can be found in Crosson (2008). Both instruments were plumbed to sample air from a continuous stream of either atmospheric air, pulled from an inlet mounted outside the vehicle on the top of the sampling mast, or from known calibration standard tanks. The inlet line consisted of $1 / 4$ in. OD Synflex tubing and was split to connect to a series of three-way valves (SS-42GXLS4, Swagelok Inc., Solon, OH) inside the vehicle to allow the user to choose whether the air sampled by the spectrometers was an atmospheric or reference gas sample (Fig. 1b). Downstream of the spectrometers, the sampling line was connected to another three-way valve to control whether the sample stream is pulled by a $12 \mathrm{~V}$ pump or is vented to atmosphere, which was necessary during the measurement of reference gases from high-pressure gas cylinders. Two different reference gases directly tied to the National Oceanic and Atmospheric Administration (NOAA) Climate Monitoring and Diagnostics Laboratory (CMDL) network $\mathrm{CO}_{2}, \mathrm{CO}$, and $\mathrm{CH}_{4}$ standards were introduced into the cavity ring-down spectrometer sampling streams before and after each measurement campaign in order to standardcorrect raw instrument data using a two-point slope and intercept linear correction. A wall-mount, flat-screen monitor with touch screen capabilities was mounted to the side of the instrument rack in order to interface with both spectrometer instruments (ERG-45-233-200, Ergodirect, San Carlos, CA) via a four-port KVM switch (GCS1804, IOGear, Foothill Ranch, CA), which was also linked to wireless mouse and keyboard components.

In addition, atmospheric $\mathrm{O}_{3}$ and $\mathrm{NO}_{x}$ instruments were installed on the instrument rack and plumbed with independent atmospheric inlets mounted to the telescoping sampling mast (ozone model 205, nitric oxide model 410, 2B Technologies, Boulder, CO; see http://www.twobtech.com/downloads205. htm and http://www.twobtech.com/downloads410.htm for additional technical specifications). Both the $\mathrm{O}_{3}$ and $\mathrm{NO}_{x}$ instruments were set to output $10 \mathrm{~s}$ averaged data logged by an external datalogger (CR3000, Campbell Scientific, Logan, UT).

A portable atmospheric aerosol spectrometer (Model 1.109, Grimm Technologies, Douglasville, GA; see http://www.dustmonitor.com/Research/1109.htm for additional technical specifications) was installed to provide continuous measurements of real-time particle size and mass distribution with a $10 \mathrm{~s}$ running average measurement 
frequency. The aerosol spectrometer was mounted to the instrument rack directly below the roof access hole to minimize the path length and curvature of the sampling line attached to the telescoping sampling mast above the roof of the vehicle. The instrument was plumbed using flexible $5 \mathrm{~mm}$ conductive tubing. In practice, this instrument was only utilized in stationary mode. However, the lab is also equipped with an isokinetic stainless-steel sampling probe at the atmospheric inlet to facilitate collection of accurate aerosol measurements when the vehicle is in motion (1.152, Grimm Technologies, Douglasville, GA; see http://vx083000.server1.viwefix.cz/domain/flox/files/ 01_imise-grimm/grimm_1.10x_lpn_de_akd_090206.pdf for additional isokinetic inlet technical specifications).

An Airmar weather station instrument (model 200WX WeatherStation, Airmar Technology, Milford, NH) was installed for the collection of meteorological data. The unit was mounted to the top of the telescoping sampling mast and was small enough that the sampling mast could still be easily collapsed into the vehicle without instrument removal. Onesecond frequency measurements of temperature, relative humidity, barometric pressure, and both true and apparent wind speed and direction were logged to an external laptop using Airmar WeatherCaster software.

A Garmin GPS instrument was mounted to the roof of the vehicle to collect geospatial coordinate data and was wired to interface with the Campbell Scientific CR3000 datalogger mounted inside the vehicle (GPS16X-HVS GPS Receiver, Campbell Scientific, Logan, UT). Geospatial position, vehicle speed, direction, and altitude were logged to the datalogger at a $5 \mathrm{~s}$ frequency.

\subsection{Creating a stable instrument power supply}

The electrical system was designed to provide power to instrument components from one of three electrical sources (utility line power when stationary, generator when stationary, or vehicle alternator when in motion) without interruption in power supply while switching among sources. Figure 2 illustrates the major components and connectivity associated with the design of this electrical system.

Electrical power supplied to instrumentation in the mobile lab was provided as $110 \mathrm{VAC}$ via an inverter-charger or 12 VDC, depending on the specific power requirements of individual components. The 110 VAC power was supplied via receptacles mounted to the rear, left wall of the van interior, with the 12 VDC supply located just below the 110 VAC receptacle bank (Fig. 1).

The inverter-charger was a $12 \mathrm{~V}, 3000 \mathrm{~W}$, pure sine-wave inverter that served a number of different functions (model 12-3000IC, Newmar, Newport Beach, CA). When the van was plugged in to utility power or generator power via the external power port, the inverter functioned to (1) provide $\mathrm{AC}$ power to the $\mathrm{AC}$ receptacles via an electric panel distribution box with four circuits having $20 \mathrm{~A}$ breaker protection

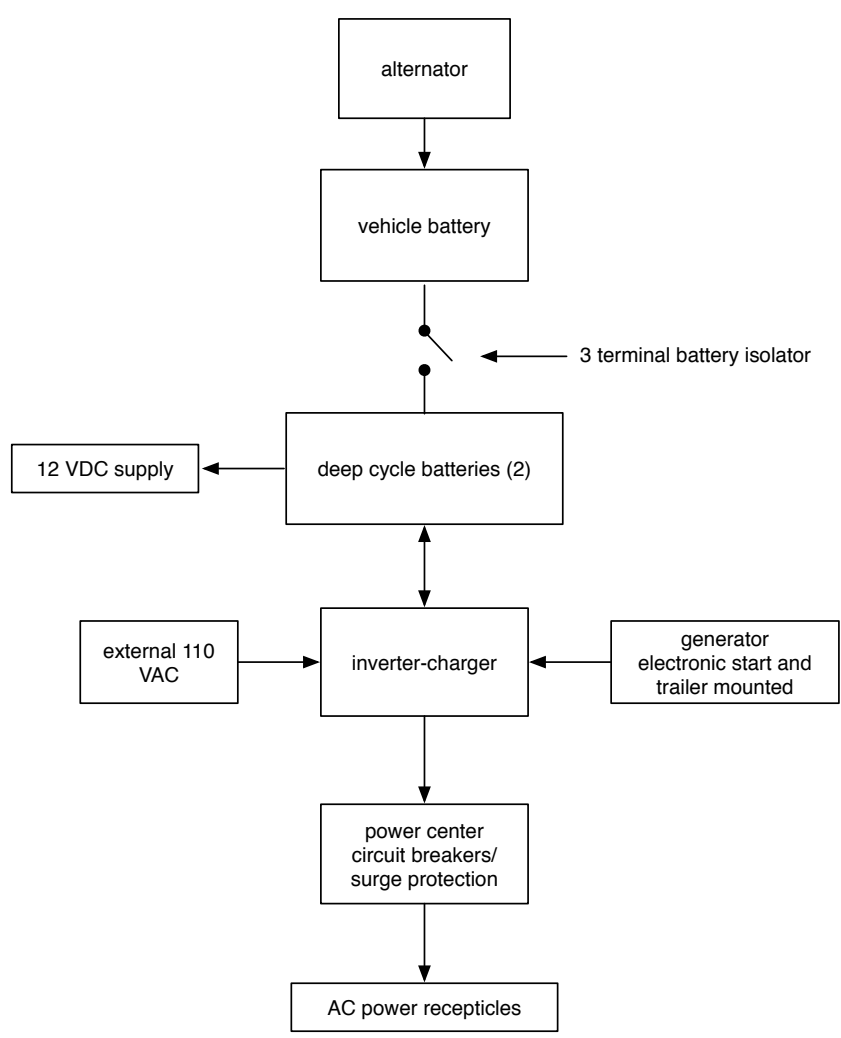

Figure 2. Diagram of the electrical system components and connectivity.

(one breaker per receptacle box) and (2) charge the deepcycle battery bank and provide $12 \mathrm{VDC}$ power to the $12 \mathrm{VDC}$ terminals. When the van was not plugged in to utility or generator power and instead was either stationary (engine off) or in motion (driving - engine on), the inverter-charger provided 110 VAC from the 12 VDC supply associated with a deep-cycle battery bank (Figs. 1 and 2). When the van was stationary with the engine off, the inverter pulled power only from the deep-cycle battery bank. When the van was in motion, a solenoid switch (54-98-002, Bargman, Plymouth, MI) located under the vehicle hood provided electrical connectivity between the deep-cycle battery bank in the rear of the vehicle and the vehicle starting battery. Under these conditions, the factory-installed vehicle alternator functioned to charge both the vehicle starting battery and the deep-cycle battery bank. The connectivity between the vehicle starting battery and the deep-cycle battery bank was provided by means of a $2 / 0$ cable that entered the van through a pre-drilled electrical conduit hole under the steering wheel and was routed under the plastic running boards on the driver's side of the vehicle.

The battery bank consisted of two deep-cycle batteries (model SRM-27, 66 Ah, Interstate Batteries, Dallas, TX, USA), wired in parallel and connected to the invertercharger. The battery bank was located in an air-tight Pelican box ( $0.40 \mathrm{~m}$ width; $0.46 \mathrm{~m}$ length; $0.27 \mathrm{~m}$ height $)$ mounted 
to the floor in the rear of the vehicle and vented to atmosphere via a hole inside the box through the floor of the vehicle (Fig. 1).

In operation, with all instruments running, the total maximum power consumption was approximately $900 \mathrm{~W}$. The system was operated with all instrument components running simultaneously for extended time periods, where the factoryinstalled alternator was sufficient to sustain uninterrupted power to all system components. The vehicle was driven multiple times between northern Utah, USA (Salt Lake City), and southern California, USA (San Diego and Los Angeles), with drive duration exceeding $12 \mathrm{~h}$ and no power loss to any of the instrument components. In addition, the capacity of the battery bank was designed to sustain power for approximately $1 \mathrm{~h}$ when functioning as the sole power source for the electrical system. In practice, the maximum time period experienced in the field did not exceed $45 \mathrm{~min}$, where no power interruption was observed during that time.

\subsection{Measurement locations}

In 2012 and 2013, we utilized the mobile observatory to collect data from three geographic regions in the western USA: northern Utah, southern California, and central Idaho.

The Utah driving transects were performed both along the Wasatch Front, a metropolitan region in the north-central part of the state with a population of approximately 1.7 million, and repeatedly within the Salt Lake Valley, the largest metropolitan area of the Wasatch Front, with a population of approximately 1.2 million. Driving routes in the Salt Lake Valley were designed to capture urban-to-rural and elevation gradients, differences in traffic features and density across the urban landscape, and emissions point source features.

The mobile observatory was also deployed to collect data associated with Idaho's Trinity Ridge wildfire in August 2012. The Trinity Ridge Fire occurred in the Boise National Forest, approximately $7 \mathrm{mi}$. northwest of Featherville, Idaho, and burned approximately 150000 acres. The mobile lab was driven inside the incident command-restricted area and sampled atmospheric air adjacent to the active fire line, which was visible from the road.

The southern California transects were performed in the broader Los Angeles Basin and greater San Diego metropolitan areas. The greater Los Angeles metropolitan area, including Los Angeles and Orange - and parts of Ventura, Riverside, and San Bernardino - counties, encompasses $87945 \mathrm{~km}^{2}$ and has a population of 18 million people. Five transects covering different parts of the region were repeated at midday and in the evening during winter, spring, summer, and fall of 2013. Transects were designed to span the Los Angeles Basin; to target major emission sources such as power plants, landfills, and oil refineries; and to sample different road sizes and representative land cover types. Images of the exterior and interior of the mobile observatory in field operation are shown in Fig. 3.

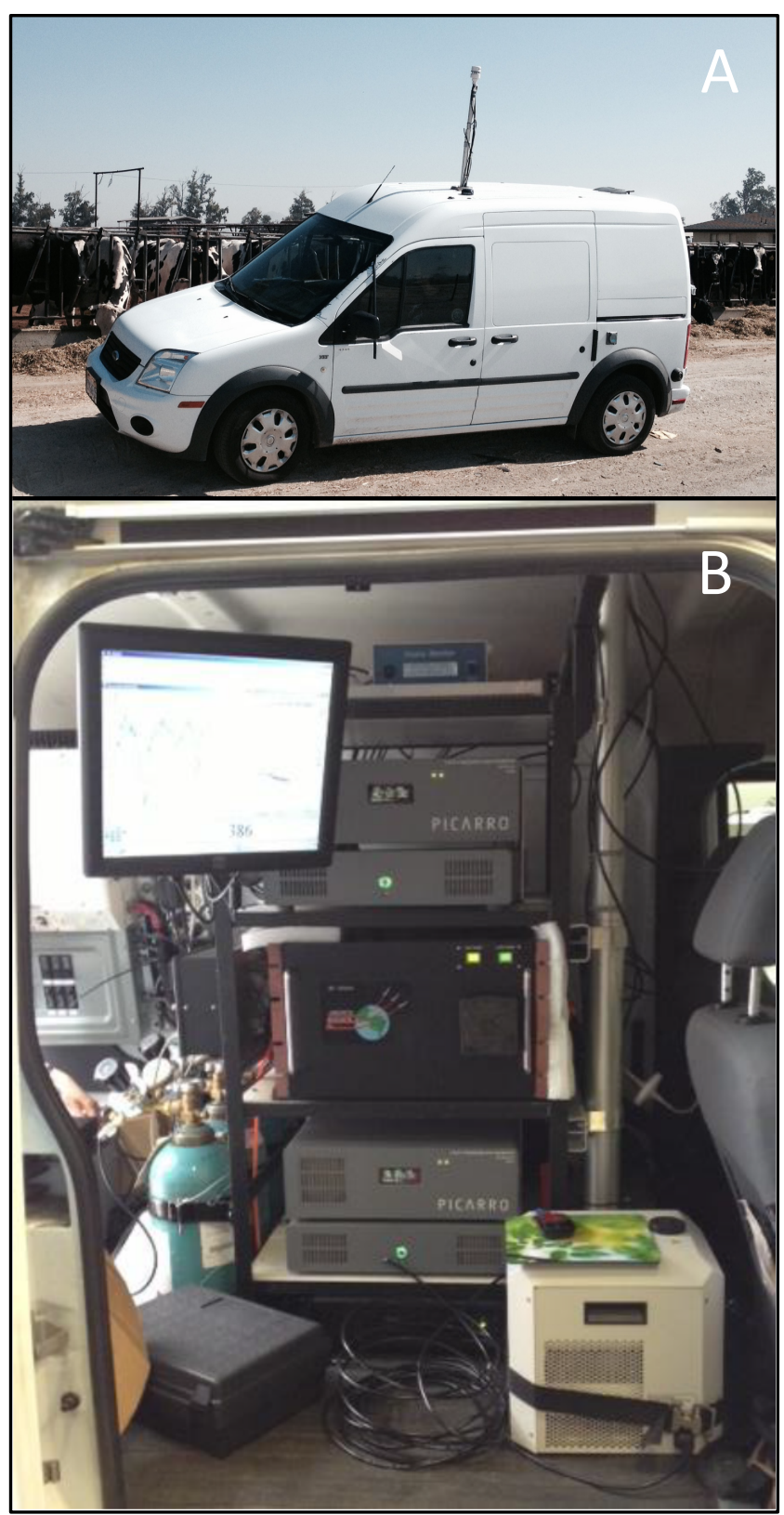

Figure 3. Images of the exterior (a) and interior (b) of the mobile observatory in operation.

\subsection{Data analyses}

Data streams associated with all instrument components were collected and post-processed following each data collection period. Both of the Picarro trace gas spectrometers were equipped with independent solid-state hard drives, where daily data files were stored. Data streams associated with GPS, $\mathrm{O}_{3}$, and $\mathrm{NO}_{x}$ instruments were stored using an external datalogger, and meteorological data were collected and stored with a laptop computer. Data streams collected on different platforms and frequencies were synchronized 
based on the user's cell phone time. Discrepancies between each instrument time and the user's cell phone time were recorded before and after each transect. During any given transect (up to $12 \mathrm{~h}$ ), no appreciable instrument time drift was observed. We corrected each data stream for time lag against the user's cell phone clock before time synchronization with MATLAB software (Mathworks, www.mathworks. com/products/matlab) that linearly interpolated data and resampled data at a uniform $5 \mathrm{~s}$ interval. We matched the $\mathrm{CO}_{2}$ data streams with correlation analysis to account for different response times between the two Picarro instruments. Similarly, we used GPS location to check synchronization of Garmin and Airmar data streams. Trace gas data and geospatial data were combined to generate spatial information using ArcGIS software (www.esri.com) and Google Earth. The legend scale for all map graphics was determined based on natural breaks classification (Jenks optimization).

All trace gas data presented here are shown as mole fractions above background levels (referred to here as "excess"). To calculate excess mole fractions, background monthly mean mole fractions for $\mathrm{CO}_{2}, \mathrm{CO}$, and $\mathrm{CH}_{4}$ were obtained from the NOAA Global Monitoring Division (GMD) station in Wendover, Utah, for the Utah and the Boise National Forest locations. Because a NOAA GMD measurement location for obtaining background mole fraction was not available near the Los Angeles area, minimum measurement values for each gas for a given season were used to estimate the background.

\section{Observatory applications}

Here we describe the data capacity associated with the mobile observatory's use as a tool to acquire continuous data and for investigating atmospheric research questions related to both public health and the carbon cycle. We present data illustrating the spatial dynamics of atmospheric criteria pollutants along city roads, carbon dioxide dynamics of urban regions at multiple spatial and temporal scales, methane emissions of both known and unknown point sources, and relationships between trace gas species associated with wildfire emissions.

Significant fine-scale spatial structure associated with atmospheric criteria pollutants was observed in the Salt Lake Valley, with implications for health, air quality policies, and greenhouse gas emissions. Figure 4 shows carbon monoxide mole fractions collected along a stop-lighted highway (Bangerter Highway) in the Salt Lake Valley, Utah. The Bangerter Highway runs north-south across the valley and is parallel to the major interstate highway within the valley, Interstate 15. On the Bangerter Highway the vehicle speed limit is $50 \mathrm{mph}$, but there are multiple intersections with stop lights. In traffic-light-controlled intersections, we continuously observed elevated $\mathrm{CO}$ and $\mathrm{CO}_{2}$ mole fractions (only $\mathrm{CO}$ data provided for brevity); $\mathrm{CO}$ mole fractions routinely

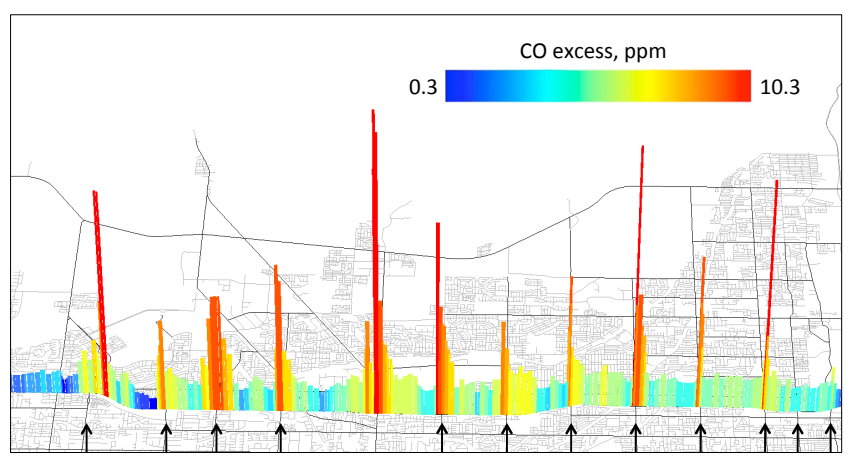

Figure 4. The CO mole fraction along a north-south segment of Bangerter Highway in Salt Lake Valley, Utah, USA. Values shown represent mole fraction above background mole fraction obtained from Wendover, Utah. The color bar shows the range of values observed. The underlying black and white grid shows roads, where the highest mole fraction values (red peaks) coincide with intersection locations. Intersections associated with traffic signals are shown with black arrows.

approached $10 \mathrm{ppm}$ or greater above ambient background levels. The current EPA primary limits for CO are $9 \mathrm{ppm}$ measured over $8 \mathrm{~h}$, and $35 \mathrm{ppm}$ measured over a single-hour period (EPA, 2010). These transect observations suggest that individuals associated with either businesses or residences located near traffic-controlled intersections may be exposed to a much higher health risk, as stationary measurement sites do not provide the spatial resolution necessary to identify these patterns.

The urban dome concept has been discussed in terms of both thermal and trace gas parameters (NRC, 2010), yet the spatial nature of this dome is largely undescribed. Very little information exists regarding the variation in magnitude, structure, and spatial extent of trace gas urban domes. Virtually all state and federal observations are from limited fixed locations. Repeated transects across Salt Lake Valley along a route designed to capture gradients in urban development, urban form, and traffic density revealed significant changes in the magnitude and pattern of emissions across the Salt Lake Valley over the course of a single day (Fig. 5). We drove the same route in the morning (08:00-11:00), afternoon (14:0017:00), and nighttime (20:00-23:00) (Fig. 5a, b, and c, respectively) in January 2013. Here we observed elevated carbon dioxide levels varied from 18.0 to $787.4 \mathrm{ppm}$ above the average January background mole fraction measured at the NOAA baseline station in Wendover, Utah. $\mathrm{CO}_{2}$ mole fractions were highest in and surrounding downtown Salt Lake City in the morning, with maximums decreasing in the afternoon with increases in the daytime mixed boundary layer and increasing again at night as the mixed boundary layer decreased in size. Even near the outer perimeter of the Salt Lake City urban area, we observed that $\mathrm{CO}_{2}$ values varied from 18 to $40.2 \mathrm{ppm}$ above background mole fractions. These 
Salt Lake Valley, January 4, 2013

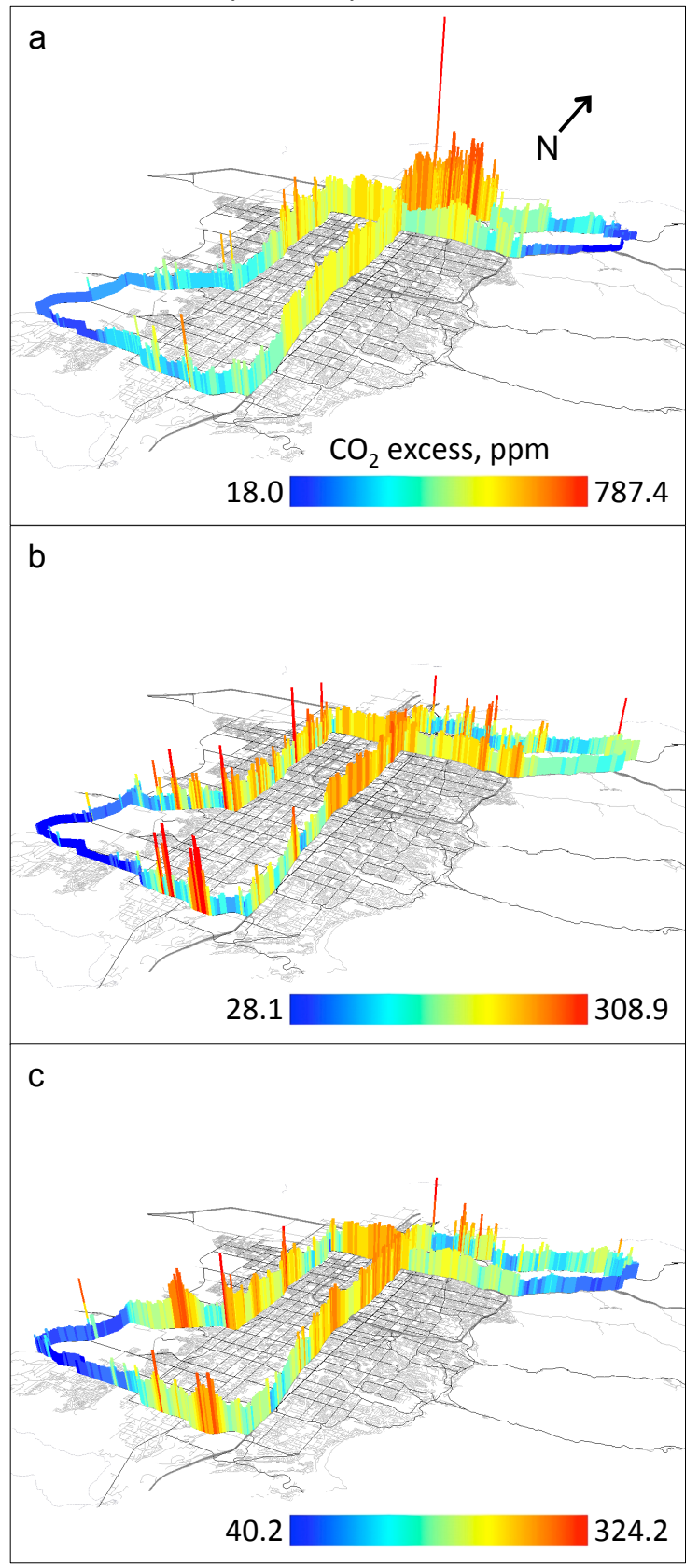

Figure 5. The $\mathrm{CO}_{2}$ mole fraction across Salt Lake Valley, Utah, USA. Morning, afternoon, and nighttime periods are shown in panels a, b, and c, respectively. Values shown represent mole fraction above background mole fraction obtained from Wendover, Utah. The underlying black and white grid shows roads, and the color bar shows the range of values observed.

elevated values may be caused, in part, by the advection of air across the Salt Lake Valley.

The mobile observatory was also used to explore greenhouse gas emissions dynamics at the regional scale. In a route along the Wasatch Front, a geographic region with approx-

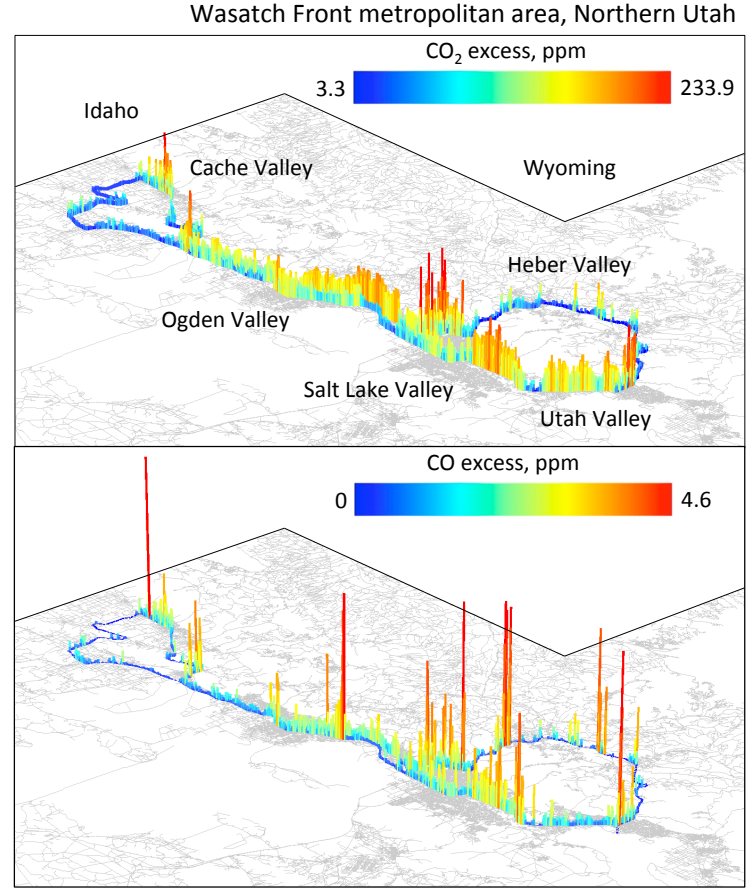

Figure 6. The $\mathrm{CO}_{2}$ mole fraction along the Wasatch Front metropolitan area in northern Utah, USA. Values shown represent mole fraction above background mole fraction obtained from Wendover, Utah. The underlying black and white grid shows roads, and the color bar shows the range of values observed.

imately $80 \%$ of the total population of the state of Utah, there are extensive spaces that are characterized as either urban or non-urban agricultural (Fig. 6). Urbanized areas along this $200 \mathrm{~km}$ transect had excess $\mathrm{CO}_{2}$ levels that were 3.3 to $233.9 \mathrm{ppm}$. Elevated $\mathrm{CO}_{2}$ mole fractions were highest in the Cache Valley (e.g., Logan), Ogden Valley (e.g., Ogden), Salt Lake Valley (e.g., Salt Lake City), and Utah Valley (e.g., Provo) but tapered off quickly when leaving the highly urbanized zones. Consistent with $\mathrm{CO}_{2}$ patterns, $\mathrm{CO}$ values were elevated in urban regions, but the signals tended to be more variable. It is worth noting that with limited exception the entire route comprised controlled-access highways or freeways, without intersections and traffic signals impacting vehicle speed.

In addition to $\mathrm{CO}_{2}$ and $\mathrm{CO}$, cities can be regions of fugitive methane emissions. Some of the methane sources within cities include emissions associated with combustion processes, fugitive emissions associated with leaks from compressed natural gas filling stations, underground transmission and distribution pipelines, and waste disposal including sewage treatment plants and landfills. We utilized the mobile observatory to investigate atmospheric methane dynamics in and around landfills and to detect fugitive methane leaks in the Salt Lake Valley urban ecosystem. We drove a transect from the east side of the valley just south of downtown Salt Lake City to the west side of the valley, where the 


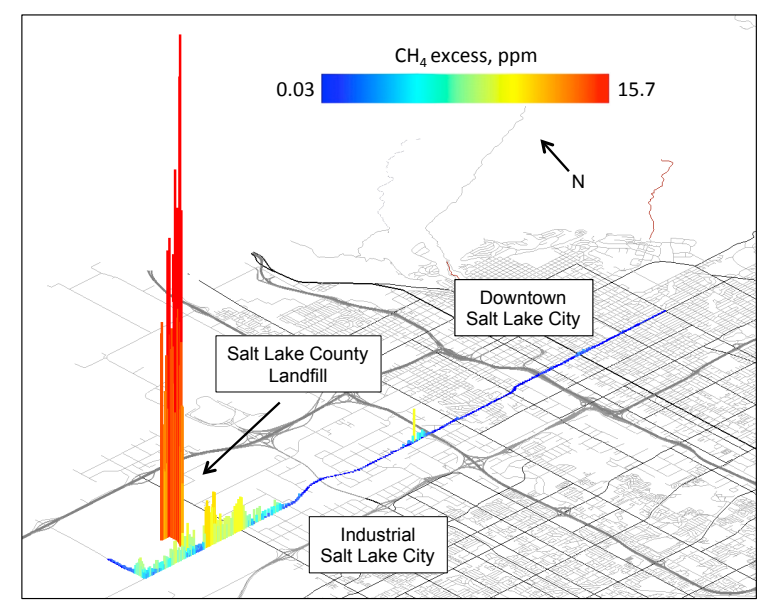

Figure 7. The $\mathrm{CH}_{4}$ mole fraction along an east-west road transect in Salt Lake Valley, Utah, USA. Values shown represent mole fraction above background mole fraction obtained from Wendover, Utah. The Salt Lake County landfill, located in the northwest of the valley, is shown. The underlying black and white grid shows roads, and the color bar shows the range of values observed.

Salt Lake County landfill is located in the industrial sector of the valley (Fig. 7). We found methane mole fractions near background levels (approximately $1.9 \mathrm{ppm}$ ) along the entire transect path, with the exception of the road segment adjacent to the landfill, and inside the landfill area, where mole fractions were nearly an order of magnitude greater, around $17 \mathrm{ppm}$. We were also able to detect fugitive methane leaks across the Salt Lake Valley (Fig. 8). We found multiple locations where methane mole fractions were double the background mole fraction as well as differences in the magnitude and spatial extent of hot spot areas, with some locations associated with fairly discrete peaks of methane and others with more widespread spatial patterns of excess. Repeated measurements of the same roadway across seasons indicated that methane hot spots/leaks tended to reoccur in the same locations over time (Fig. 9).

The mobile observatory was used to measure trace gas emissions from the Trinity Ridge wildfire that burned in the Boise National Forest of Idaho in the late summer of 2012. Figure 10 shows a transect driven on 29 August starting from the junction of Sun Valley Highway and Forest Road 61, where the sheriff command post restricting public access was located, to Featherville, Idaho, and back. Descent to the valley floor during the morning time period and prior to convective expansion of the boundary layer made it possible to sample a stable atmosphere highly impacted by fire emissions built up during the previous nighttime period and characterized by very low visibility (Fig. 10). Mole fractions of $\mathrm{CO}_{2}, \mathrm{CO}$, and $\mathrm{CH}_{4}$ were significantly elevated to greater than $60.0,6.0$, and $0.8 \mathrm{ppm}$ above background mole fractions, respectively (Fig. 10). We observed that the ratios of $\mathrm{CO}$ excess to $\mathrm{CO}_{2}$ excess and $\mathrm{CH}_{4}$ excess to $\mathrm{CO}_{2}$ excess ranged from

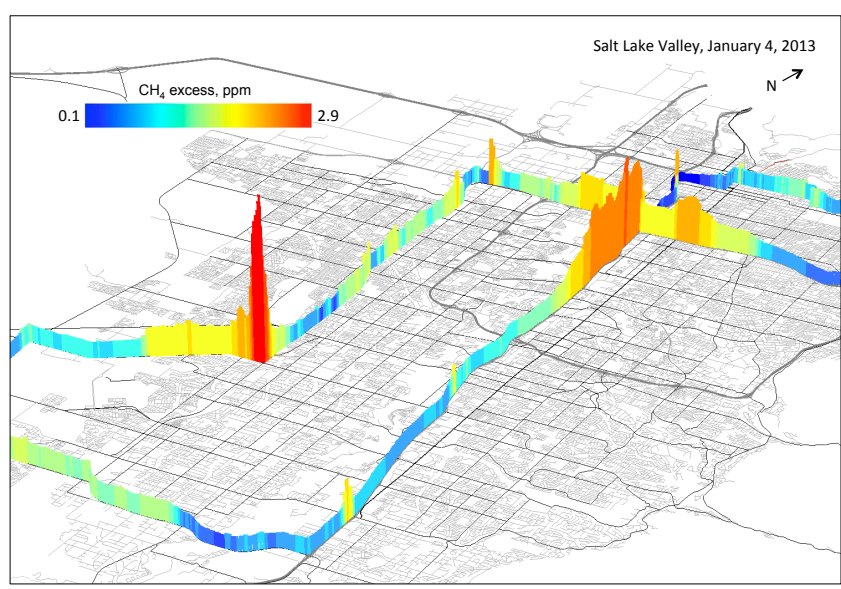

Figure 8. The $\mathrm{CH}_{4}$ mole fraction across Salt Lake Valley, Utah, USA. Values shown represent mole fraction above background mole fraction obtained from Wendover, Utah. The underlying black and white grid shows roads, and the color bar shows the range of values observed.

0.009 to 4.8 and 0.001 to 0.8 , respectively. However, both ratios were very stable during sampling of the emissions layer, with ranges from 0.10 to 0.12 and 0.009 to 0.01 and average values of $0.1 \pm 0.0009$ and $0.01 \pm 0.0002$ for $\mathrm{CO}: \mathrm{CO}_{2}$ and $\mathrm{CH}_{4}: \mathrm{CO}_{2}$ excess, respectively.

\section{Future directions and opportunities}

Here we have presented some examples that highlight the utility of the mobile platform for addressing carbon-cycleand public-health-related questions. However, there are many additional applications for which this mobile laboratory would prove useful. In particular, this observatory is well suited for providing high spatial and temporal resolution measurements to link with current emissions model products (e.g., Hestia) (Gurney et al., 2012) for validation, improvement, and further product development. This observatory also provides a cost-effective mechanism to collect data between different permanent measurement stations to integrate measurements across space and time and also provide vital in situ data required for modeling the trajectory, dispersion, and chemical composition of the atmosphere from discreet plume events to patterns at larger spatial scales for both stochastic events and anthropogenic emissions across different geographic areas (Fleming et al., 2012). Indeed, no other atmospheric measurement technique can combine measurements of point source emitters and well-mixed air at the regional scale with the ease of administrative effort required for on-road measurement, which contrasts to permissions required for airborne measurement campaigns. It is worth noting that this system, as with any system designed for on-road measurements, is necessarily limited to the road network, which has associated measurement limitations. In particu- 


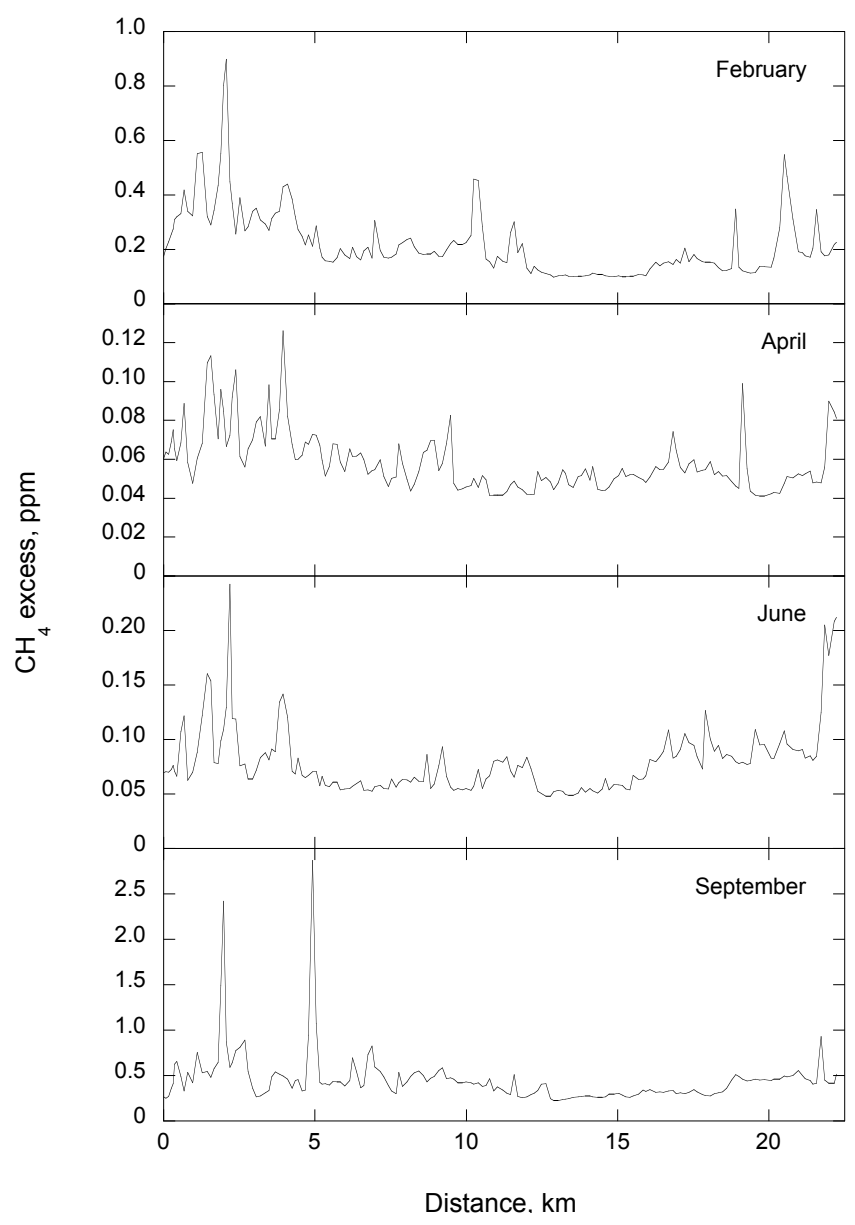

Figure 9. The $\mathrm{CH}_{4}$ mole fraction along a road transect in Los Angeles, California, USA. The same transect was repeated over both morning and evening time periods for all four seasons of the year. The distance from the origin ( $x$ axis) represents the distance traveled along the road, and methane mole fraction ( $y$ axis) represents the average mole fraction above background for combined morning and evening time periods within each seasonal time period.

lar, the distance to different emission sources, both mobile (other vehicles on the road for example) and stationary, and thus signal strength for mobile observations is determined by external confounding factors. It is also not possible to separate a measured emissions signal comprised of more than one point source into its component parts or determine their relative contribution to the total emission signal unless the point emission source can be linked because of its association with a specific atmospheric constituent - methane for example is linked to certain processes and not others. And lastly, as with many types of atmospheric measurements, a big challenge is to relate measured atmospheric concentrations to land surface fluxes. However, at least in mobile mode, this platform was not designed to measure fluxes, but rather to provide spatial information about greenhouse gas concentration fields.

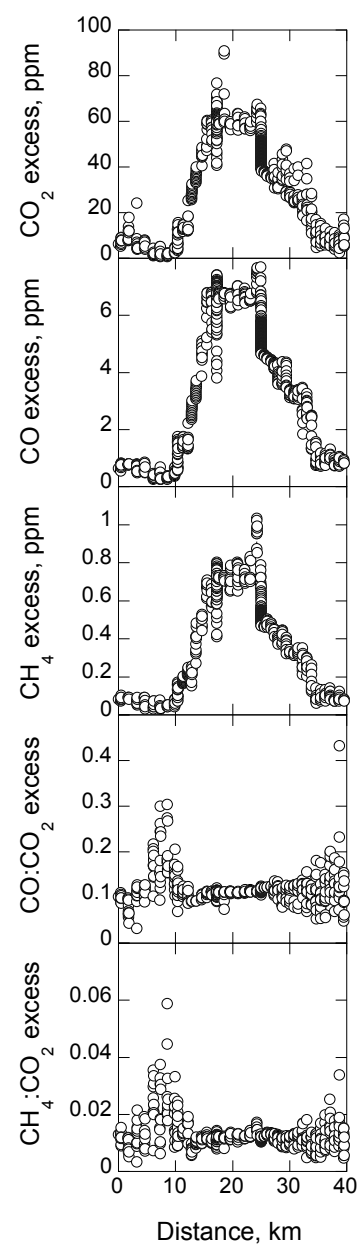

Figure 10. $\mathrm{CO}_{2}, \mathrm{CO}$, and $\mathrm{CH}_{4}$ mole fractions and the ratio of $\mathrm{CO}$ and $\mathrm{CH}_{4}$ to $\mathrm{CO}_{2}$ measured while driving along Forest Road 61, adjacent to the active fire line and inside the public restricted incident command area for the Trinity Ridge wildfire in Idaho, USA. Values shown represent mole fraction above background mole fraction obtained from Wendover, Utah.

The design of the vehicle, e.g., the standard instrument rack and power capabilities, also provides great flexibility for adding different instruments to the vehicle for targeted sampling campaigns - a quantum cascade laser sensor for ethane was added to the vehicle in June 2013 for attribution of methane leaks in Los Angeles (Hopkins et al., 2015). In addition, recent studies linking $\mathrm{CO}_{2}$ mole fraction with criteria pollutants and air pollution mortality (Jacobson, 2008, 2010) call for a more in-depth examination of the correlation between criteria pollutants and also their relationship to $\mathrm{CO}_{2}$ across different urban sectors.

Lastly, the mobile observatory described here represents a great outreach opportunity. Because of its compact size and system design, it provides a great model for deployment to both primary and secondary schools, as a tool for use in combination with higher-education courses, and for educating the 
general public and policy makers. Such outreach activity is critical for providing the education necessary for a better understanding of how human activity and associated fossil fuel combustion impact the atmosphere across multiple spatial and temporal scales, but it is also necessary for providing the basis for making informed policy decisions and provides a mechanism to monitor and enforce greenhouse gas emissions and air quality regulations in the future.

Acknowledgements. The funding for the development and construction of the mobile laboratory, subsequent data collection, and analyses was provided by the US Dept. of Energy Office of Science Biological and Environmental Research (BER) division.

Edited by: G. Phillips

\section{References}

Briber, B. M., Hutyra, L. R., Dunn, A. L., Raciti, S. M., and Munger, J. W.: Variations in atmospheric $\mathrm{CO} 2$ mixing ratios across a Boston, MA urban to rural gradient, Land, 2, 304-327, 2013.

Brioude, J., Angevine, W. M., Ahmadov, R., Kim, S.-W., Evan, S., McKeen, S. A., Hsie, E.-Y., Frost, G. J., Neuman, J. A., Pollack, I. B., Peischl, J., Ryerson, T. B., Holloway, J., Brown, S. S., Nowak, J. B., Roberts, J. M., Wofsy, S. C., Santoni, G. W., Oda, T., and Trainer, M.: Top-down estimate of surface flux in the Los Angeles Basin using a mesoscale inverse modeling technique: assessing anthropogenic emissions of $\mathrm{CO}, \mathrm{NO}_{\mathrm{x}}$ and $\mathrm{CO}_{2}$ and their impacts, Atmos. Chem. Phys., 13, 3661-3677, doi:10.5194/acp13-3661-2013, 2013.

Brondfield, M. N., Hutyra, L. R., Gately, C. K., Raciti, S. M., and Peterson, S. A.: Modeling and validation of on-road CO2 emissions inventories at the urban regional scale, Environ. Pollut., 170, 113-123, 2012.

Bukowiecki, N., Dommen, J., Prevot, A. S. H., Richter, R., Weingartner, E., and Baltensperger, U.: A mobile pollutant measurement laboratory - measuring gas phase and aerosol ambient concentrations with high spatial and temporal resolution, Atmos. Environ., 36, 5569-5579, 2002.

Canadell, J. G., Le Quere, C., Raupach, M. R., Field, C. B., Buitenhuis, E. T., Ciais, P., Conway, T. J., Gillett, N. P., Houghton, R. A., and Marland, G.: Contributions to accelerating atmospheric $\mathrm{CO} 2$ growth from economic activity, carbon intensity, and efficiency of natural sinks, Proc. Natl. Aca. Sci., 104, 18866-18870, 2007.

Crosson, E. R.: A cavity ring-down analyzer for measuring atmospheric levels of methane, carbon dioxide, and water vapor, Appl. Phys. B, 92, 403-408, 2008.

Dhakal, S: GHG emissions from urbanization and opportunities from urban carbon mitigation, Curr. Op. Environ. Sustain., 2, 277-283, 2010.

Drewnick, F., Böttger, T., von der Weiden-Reinmüller, S.-L., Zorn, S. R., Klimach, T., Schneider, J., and Borrmann, S.: Design of a mobile aerosol research laboratory and data processing tools for effective stationary and mobile field measurements, Atmos. Meas. Tech., 5, 1443-1457, doi:10.5194/amt-5-1443-2012, 2012.

EPA: Policy Assessment for the Review of the Carbon Monoxide National Ambient Air Quality Standards, United States Environmental Protection Agency, 2010.

Farrell, P., Culling, D., and Leifer, I.: Transcontinental methane measurements: Part 1. A mobile surface platform for source investigations, Atmos. Environ., 74, 422-431, 2013.

Fleming, Z. L., Monks, P. S., and Manning, A. J.: Review: Untangling the influence of air-mass history in interpreting observed atmospheric composition, Atmos. Res., 104-105, 1-39, 2012.

Gurney, K. R., Mendoza, D. L., Zhou, Y., Fischer, M. L., Miller, C. C., Geethakumar, S., and de la Rue du Can, S.: High resolution fossil fuel combustion $\mathrm{CO} 2$ emission fluxes for the United States, Environ. Sci. Technol., 43, 5535-5541, 2009.

Gurney, K. R., Razlivanov, I., Song, Y., Zhou, Y., Benes, B., and Abdul-Massih, M.: Quantification of fossil fuel CO2 emissions on the building/street scale for a large U.S. city, Environ. Sci. Technol., 46, 12194-12202, 2012.

Haiduc, I. and Beldean-Galea, M. S.: Variation of greenhouse gases in urban areas-case study: $\mathrm{CO} 2, \mathrm{CO}$ and $\mathrm{CH} 4$ in three Romanian cities, INTECH open access, ISBN: 9789533073071, 2011.

Herndon, S. C., Jayne, J. T., Zahniser, M. S., Worsnop, D. R., Knighton, B., Alwine, E., Lamb, B. K., Zavala, M., Nelson, D. D., McManus, J. B., Shorter, J. H., Canagaratna, M. R., Onasch, T. B., and Kolb, C. E.: Characterization of urban pollutant emission fluxes and ambient concentration distributions using a mobile laboratory with rapid response instrumentation, Faraday Discuss., 130, 327-339, 2005.

Hopkins, F. M., Bush, S. E., Ehleringer, J. R., Lai, C. T., Kort, E. A., Blake, D. R., and Randerson, J. T.: Spatial patterns and source attribution of urban methane sources in the Los Angeles Basin, J. Geophys. Res.-Atmos., in revision, 2015.

Hussein, T., Johansson, C., Karlsson, H., and Hansson, H: Factors affecting non-tailpipe aerosol emissions from paved roads: Onroad measurements in Stockholm, Sweden, Atmos. Environ., 42, 688-702, 2008.

IEA: World Energy Outlook, International Energy Agency, 2008.

IPCC: Climate Change: The Physical Science Basis, Intergovernmental Panel on Climate Change, 2013.

Jackson, R. B., Down, A., Phillips, N. G., Ackley, R. C., Cook, C. W., Plata, D. L., and Zhao, K.: Natural gas pipeline leaks across Washington, DC, Environ. Sci. Technol., 48, 2051-2058, 2014.

Jacobson, M. Z.: On the causal link between carbon dioxide and air pollution mortality, Geophys. Res. Lett., 35, L03809, doi:10.1029/2007GL031101, 2008.

Jacobson, M. Z.: Enhancement of local air pollution by urban $\mathrm{CO} 2$ domes, Environ. Sci. Technol., 44, 2497-2502, 2010.

Kennedy, C. A., Ramaswami, A., Carney, S., and Dhakal, S.: Greenhouse gas emission baselines for global cities and metropolitan regions, World Bank Commissioned report presented in the plenary of the 5th Urban Research Symposium on Cities and Climate Change, 28-30 June 2009, Marseille, France, 2009.

Kolb, C. E., Herndon, S. C., McManus, J. B., Shorter, J. H., Zahniser, M. S., Nelson, D. D., Jayne, J. T., Canagaratna, M. R., and Worsnop, D. R.: Mobile laboratory with rapid response instruments for real-time measurements of urban and regional trace 
gas and particulate distributions and emissions source characteristics, Environ. Sci. Technol., 38, 5694-5703, 2004.

Kort, E. A., Angevine, W. M., Duren, R., and Miller, C. E.: Surface observations for monitoring urban fossil fuel $\mathrm{CO} 2$ emissions: Minimum site location requirements for the Los Angeles megacity, J. Geophys. Res.-Atmos., 118, 1-8, 2013.

Kort, E. A., Frankenberg, C., Miller, C. E., and Oda, T.: Space-based observations of megacity carbon dioxide, Geophys. Res. Lett., 39, L17806, doi:10.1029/2012GL052738, 2012.

Lauvaux, T., Miles, N. L., Richarson, S. J., Deng, A., Stauffer, D. R., Davis, K., Jacobson, G., Rella, C., Calonder, G.-P., and DeCola, P. L.: Urban emissions of CO2 from Davos, Switzerland: The first real-time monitoring system using an atmospheric inversion technique, J. Appl. Meteorol. Climatol., 52, 2654-2668, doi:10.1175/JAMC-D-B-038.1, 2013.

Leifer, I., Culling, D., Schneising, O., Farrell, P., Buchwitz, M., and Burrows, J. P.: Transcontinental methane measurements: Part 2. Mobile surface investigation of fossil fuel industrial fugitive emissions, Atmos. Environ., 74, 432-441, 2013.

Lietzke, B. and Vogt, R.: Variability of $\mathrm{CO} 2$ concentrations and fluxes in and above an urban street canyon, Atmos. Environ., 74, 60-72, 2013.

McKain, K., Wofsy, S. C., Nehrkorn, T., Eluszkiewicz, J., Ehleringer, J. R., and Stephens, B. B.: Assessment of groundbased atmospheric observations for verification of greenhouse gas emissions from an urban region, Proc. Natl. Aca. Sci., 109, 8423-8428, 2012.

Miller, S. M., Wofsy, S. C., Michalak, A. M., Kort, E. A., Andrews, A. E., Biraud, S. C., Dlugokencky, E. J., Eluszkiewicz, J., Fischer, M. L., Janssens-Maenhout, G., Miller, B. R., Miller, J. B., Montzka, S. A., Nehrkorn, T., and Sweeney, C.: Anthropogenic emissons of methane in the United States, Proc. Natl. Aca. Sci., 110, 20018-20022, 2013.

Moore, T. O: Application of a mobile flux lab for the atmospheric measurement of emissions (FLAME), Virginia Polytechnic Institute and State University, Blacksburg, Virginia, 2009.

Nehrkorn, T., Henderson, J., Leidner, M., Mountain, M., and Eluszkiewicz, J.: WRF simulations of the urban circulation in the Salt Lake City area for CO2 modeling, J. Appl. Meteorol. Climatol., 52, 323-340, 2013.

Newman, S., Jeong, S., Fischer, M. L., Xu, X., Haman, C. L., Lefer, B., Alvarez, S., Rappenglueck, B., Kort, E. A., Andrews, A. E., Peischl, J., Gurney, K. R., Miller, C. E., and Yung, Y. L.: Diurnal tracking of anthropogenic $\mathrm{CO}_{2}$ emissions in the Los Angeles basin megacity during spring 2010, Atmos. Chem. Phys., 13, 4359-4372, doi:10.5194/acp-13-4359-2013, 2013.

NRC: Verifying Greenhouse Gas Emissions: Methods to Support International Climate Agreements, Washington DC, 2010.

Pataki, D. E., Bowling, D. R., and Ehleringer, J. R.: Seasonal cycle of carbon dioxide and its isotopic composition in an urban atmosphere: Anthropogenic and biogenic effects, J. Geophys. Res., 108, 4735, doi:10.1029/2003JD003865, 2003.

Phillips, N. G., Ackley, R. C., Crosson, E. R., Down, A., Hutyra, L. R., Brondfield, M., Karr, J. D., Zhao, K., and Jackson, R. B.: Mapping urban pipeline leaks: Methane leaks across Boston, Environ. Pollut., 173, 1-4, 2013.

Pirjola, L., Kupiainen, K. J., Perhoniemi, P., Tervahattu, H., and Vesala, H.: Non-exhaust measurement system of the mobile laboratory SNIFFER, Atmos. Environ., 43, 4703-4713, 2009.
Riley, W. J., Hsueh, D. Y., Randerson, J. T., Fischer, M. L., Hatch, J. G., Pataki, D. E., Wang, W., and Goulden, M. L.: Where do fossil fuel carbon dioxide emissions from California go? An analysis based on radiocarbon observations and an atmospheric transport model, J. Geophys. Res.-Biogeosci., 113, G04002, doi:10.1029/2007JG000625, 2008.

Schneising, O., Heymann, J., Buchwitz, M., Reuter, M., Bovensmann, H., and Burrows, J. P.: Anthropogenic carbon dioxide source areas observed from space: assessment of regional enhancements and trends, Atmos. Chem. Phys., 13, 2445-2454, doi:10.5194/acp-13-2445-2013, 2013.

Shorter, J. H., McManus, J. B., Kolb, C. E., Allwine, E. J., Lamb, B. K., Mosher, B. W., Harriss, R. C., Partchatka, U., Fischer, H., Harris, G. W., Crutzen, P. J., and Karbach, H.-J.: Methane emission measurements in urban areas in Eastern Germany, J. Atmos. Chem., 24, 121-140, 1996.

Sommers, W. T., Loehman, R. A., and Hardy, C. C.: Wildland fire emissions, carbon, and climate: Science overview and knowledge needs, Forest Ecol. Manage., 317, 1-8, 2014.

Spessa, A., van der Werf, G., Thonicke, K., Dans, J. G., Lehsten, V., Fisher, R., and Forrest, M.: Modeling vegetation fires and fire emissions, Kessel Publishing House, 2013.

Strong, C., Stwerka, C., Bowling, D. R., Stephens, B. B., and Ehleringer, J. R.: Urban carbon dioxide cycles within the Salt Lake Valley: A multiple-box model validated by observations, J. Geophys. Res., 16, D15307, doi:10.1029/2011JD015693, 2011.

Turnbull, J. C., Karion, A., Fischer, M. L., Faloona, I., Guilderson, T., Lehman, S. J., Miller, B. R., Miller, J. B., Montzka, S., Sherwood, T., Saripalli, S., Sweeney, C., and Tans, P. P.: Assessment of fossil fuel carbon dioxide and other anthropogenic trace gas emissions from airborne measurements over Sacramento, California in spring 2009, Atmos. Chem. Phys., 11, 705-721, doi:10.5194/acp-11-705-2011, 2011.

UN: World Urbanization Prospects. United Nations, Department of Economic and Social Affairs, 2011.

van der Werf, G. R., Randerson, J. T., Giglio, L., Collatz, G. J., Mu, M., Kasibhatla, P. S., Morton, D. C., DeFries, R. S., Jin, Y., and van Leeuwen, T. T.: Global fire emissions and the contribution of deforestation, savanna, forest, agricultural, and peat fires (19972009), Atmos. Chem. Phys., 10, 11707-11735, doi:10.5194/acp10-11707-2010, 2010.

van Leeuwen, T. T. and van der Werf, G. R.: Spatial and temporal variability in the ratio of trace gases emitted from biomass burning, Atmos. Chem. Phys., 11, 3611-3629, doi:10.5194/acp11-3611-2011, 2011.

Weimer, S., Mohr, C., Richter, R., Keller, J., Mohr, M., Prevot, A. S. H., and Baltensperger, U.: Mobile measurements of aerosol number and volume size distributions in an Alpine valley: Influence of traffic versus wood burning, Atmos. Environ., 43, 624-630, 2009.

Westerdahl, D., Fruin, S., Sax, T., Fine, P. M., and Sioutas, C.: Mobile platform measurements of ultrafine particles and associated pollutant concentrations on freeways and residential streets in Los Angeles, Atmos. Environ., 39, 3597-3610, 2005.

Wunch, D., Wennberg, P. O., Toon, G. C., Keppel-Aleks, G., and Yavin, Y. G.: Emissions of greenhouse gases from a North American megacity, Geophys. Res. Lett., 36, L15810, doi:10.1029/2009GL039825, 2009. 
Yokelson, R. J., Burling, I. R., Gilman, J. B., Warneke, C., Stockwell, C. E., de Gouw, J., Akagi, S. K., Urbanski, S. P., Veres, P., Roberts, J. M., Kuster, W. C., Reardon, J., Griffith, D. W. T., Johnson, T. J., Hosseini, S., Miller, J. W., Cocker III, D. R., Jung, H., and Weise, D. R.: Coupling field and laboratory measurements to estimate the emission factors of identified and unidentified trace gases for prescribed fires, Atmos. Chem. Phys., 13, 89-116, doi:10.5194/acp-13-89-2013, 2013. 